\title{
DEVELOPMENT AND DISTRIBUTION OF TECHNOLOGICAL CAPITAL IN AGRICULTURE: COMPARISON OF THE BALTIC COUNTRIES
}

\author{
Ieva Leimane, Agnese Krievina, Ligita Melece \\ Institute of Agricultural Resources and Economics, Latvia \\ ieva.leimane@arei.lv, agnese.krievina@arei.lv, ligita.melece@arei.lv
}

\begin{abstract}
The value added created in the agriculture of Latvia and other Baltic countries is still not sufficient for the adequate remuneration of the production factors and further farm development. At the same time, there have been studies, which conclude that the increase in the productivity and the resource utilization efficiency in agriculture can be achieved by technological progress and development of technological capital; and after joining the EU, substantial financial funds were made available to the farm modernization in the Baltic countries. Therefore, the paper seeks to analyse how the development of technological capital has changed the concentration of fixed assets and value added among the farms of different size in the agriculture of the Baltic countries. The concept of the Lorenz curve has been applied in the study, using DG Agri FADN data of 20042013, which corresponds to the previous EU programming periods. The use of the Lorenz curve in the economic analysis of agriculture is a rather innovative approach applied in the paper. The results show that a significant amount of investment has been made in the agriculture of the Baltic countries, along with the increase in the agricultural value added created. Although the concentration level of fixed assets and value added differs among the Baltic countries; there is a similar concentration tendency - increase of the role of the large farms and their share both in the management of fixed assets and in the generation of value added.
\end{abstract}

Keywords: investment, fixed assets, value added, agriculture, concentration.

\section{Introduction}

Small and medium-sized farms dominate in the farm structure in the Baltic countries, and their ability to create the value added is often not sufficient for the adequate remuneration of the production factors and further farm development. This is a threat both to the future survival of smaller farms and to the overall competitiveness of the agricultural sector of the Baltic countries. According to the farmers, the most significant barriers for development and reasons for low production efficiency are lack of the required production assets and difficulties in attracting funding for long-term investments in Latvia [1]. While analysing the development of agriculture in Lithuania and Estonia, researchers point out that small and medium-sized farms do not possess sufficient opportunities for investment in farm modernization and implementation of new technologies [2;3].

In a number of unconnected studies the authors point out that in agriculture the increase in output and the efficiency of use of production resources is achieved by means of technological progress, i.e. by using machinery and modernising the production process, by using more productive varieties, by introducing organisational changes in the farm management [4-6]; likewise, investments in R\&D are an important factor $[7 ; 8]$. The potential of fixed assets is also an element of the competitiveness of agricultural holdings. Fixed assets constitute the material and technical foundation of production capacity and the volume of production and economic results largely depend on utilization of this capacity [9]. According to Michael Porter, technological innovations have a direct effect on cutting the costs and differentiation of products, thereby leading to enhanced competitive advantages of an enterprise [10]. It is relatively recently, when analysing the aspects of competitiveness of the business and innovative development, the term and concept of technological capital has been evolved in research papers $[11 ; 10]$. It states that technological capital should be perceived as a combination of two components: the tangible component, which are the material assets at an enterprise's disposal and are used in production, and the intangible component, which comprises the engineering decisions at the disposal of the enterprise that are directly engaged in production and management; and it describes the innovative and productive development capability of a business [10].

Recent studies dealing with rural development issues in Europe no longer deny the existence of small and medium-sized farms: quite on the contrary - it is defined as of a critical prerequisite for a balanced development of rural area and sustainable agriculture $[2 ; 12 ; 13]$. As larger farms tend to employ less labour per unit of standard output, the liveliness of rural areas depends on the survival of a certain number of small and medium-sized farms [13]. Thereby, the raising of production efficiency of 
these farms remains to be a topical subject in research projects. Small and medium farms should improve their viability to ensure balanced development of rural area and sustainable agriculture.

Since joining the European Union (EU), agriculture and rural development support policies have undergone substantial changes in Latvia and in the other Baltic countries. Since 2004, support to longterm investments in fixed assets has been made available to farmers towards modernisation of agricultural farms and increasing the production efficiency as well as enhancing the overall competitiveness of the agricultural sector. The problem of production efficiency in agriculture of the Baltics in the context of investments in fixed assets is explored in scientific literature since then. In many cases the studies have been focusing on the changes in the level of fixed assets, which is the result of the investments supported by EU funds, and changes in the level of production efficiency caused by this $[14 ; 15]$.

The concept of the technological capital has not been a subject of the research in the field of agriculture of Latvia so far. In this context, the assessment of the development and distribution of technological capital in agriculture of Latvia compared to the other Baltic countries was set as an objective of this research.

In this study, the authors assume that technological capital is characterized by fixed assets and net investments, as well the authors believe that its constituent element is also value added - as a potential for financing further investments and development of farms, and also as an aim/result of making investment and developing of fixed assets.

In line with the objective of the study, firstly, the analysis dealt with the investments made by farms towards the development of fixed assets and the dynamics of value added formation in the agricultural sectors of the Baltic countries between 2004 and 2013. Next, by applying the Lorenz curve concept, the concentration trends of fixed assets and value added were analysed across the sector in farms of different sizes to evaluate the distribution of technological capital. This paper introduces a new approach to the analyses of development of agriculture and adopts the Lorenz curve concept to agricultural economics usually used in income economics.

\section{Materials and methods}

The principal materials used for the theoretical study are different sources of literature, e.g., scholars' articles, research papers and the reports of foreign and Latvian researchers, and institutions. Also, DG Agri Farm Accountancy Data Network (FADN) data covering the period 2004-2013, which corresponds to the previous EU budget and programming periods (2004-2006; 2007-2013), have been used as the main data source for the calculations of the study [16].

The appropriate qualitative and quantitative research methods have been used in the process of the study: monographic; content analysis and synthesis, data grouping, logical and abstract constructive etc.

The FADN data which are given in the database as farm average are generalized for the study (considering the number of the farms represented) to represent all agricultural farms covered by the FADN system. Considering the aims of the study, the authors of this paper analyse such indicators as net investment, fixed assets and value added. The indicator of net investment and fixed assets are directly retrieved from the FADN standard results (variable codes SE521 and SE441, respectively), but value added has been calculated as the difference between the total output and total intermediate consumption (i.e., SE131 - SE275); to consider the effect of the support, the value added with the balance of current subsidies and taxes (SE131 - SE275 + SE600) is also analysed in addition. To obtain the cumulative effect of the changes in net investment, the value of fixed assets of 2004 as the base level, corrected with the annual values of net investment has been used (SE441(2004) + $\left.\sum \operatorname{SE} 521(2005,2006, \ldots, 2013)\right)$.

The Lorenz Curve is a well-established economic tool, which is typically used to describe an inequality in the distribution of wealth and income in society. This graphical distribution of wealth, devised by Max Lorenz in 1906, shows the proportion of income earned by any given percentage of the population. The diagonal line shows perfectly equal income distribution; the further the actual distribution line from the diagonal line, the more unequal the size of distribution of income [17]. The paper adopts the Lorenz curve concept in the analysis to give a graphical representation of the 
distribution of the analysed objects (i.e, fixed assets and value added of agricultural farms of different size), as well as to analyse their concentration tendencies. The use of the Lorenz curve in the economic analysis of agriculture is a rather innovative approach applied in this paper. For Latvia, the distribution of fixed assets and value added is analysed for 2013 in comparison with 2004. For other Baltic countries, due to the lack of comparable data (there are no data available by farm economic sizes for the year 2004) only the distribution of 2013 is presented, still, the overall development tendencies are described only within the respective country analysis, based on the earliest available data for 2006 in Lithuania and 2008 in Estonia.

\section{Results and discussion}

\section{Development of net investment and value added}

Starting from 2004, significant investments towards development of technological capital have been made in the agricultural sectors of the Baltic countries. According to generalised FADN farm group data, total net investment amount in 2005-1013 was EUR 2555 million in Lithuania, EUR 1366 million in Latvia and EUR 872 million in Estonia. In Lithuania, this equals EUR 960 per ha of agricultural land (UAA) in these farms in 2013, in Latvia EUR 870 per ha and in Estonia EUR 840 per ha. As a result of net investments, the highest increase in the value of fixed assets is in the agriculture of Latvia (by 2.5 times), followed by Estonia (by 2.2 times) and Lithuania (by 1.9 times) (Fig. 1).

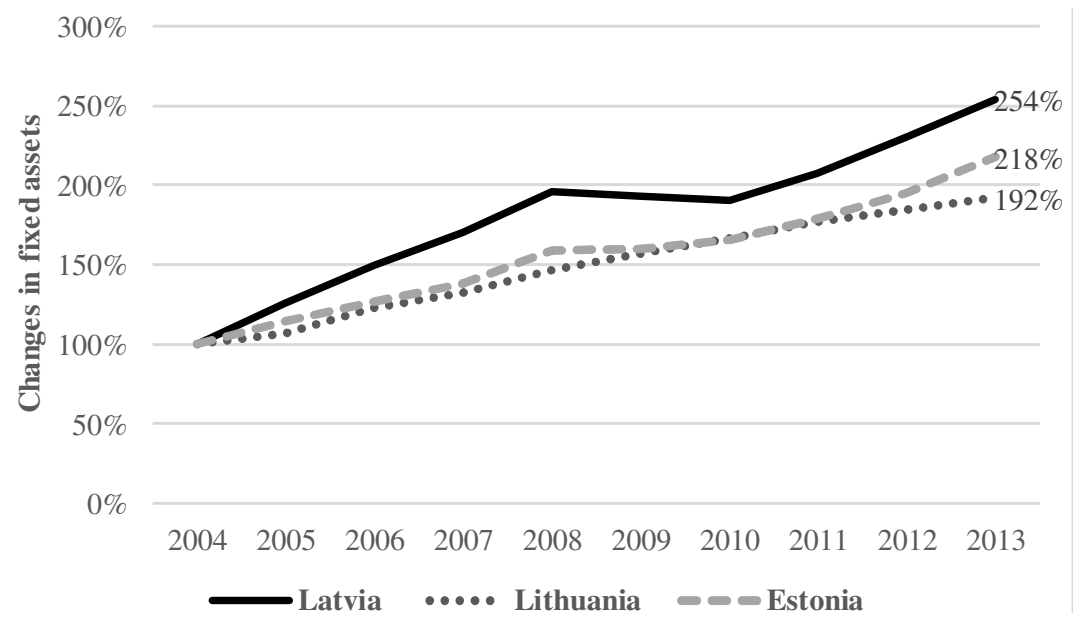

Fig. 1. Cumulative effect of the changes in net investment in the agriculture of Latvia, Lithuania and Estonia in 2004-2013 $(2004=100 \%)$

The value-added growth rate in 2004-2013 has been rather similar in all Baltic countries, and at the end of period the level was about one half higher than that of 2004 (Fig. 2). Lithuania demonstrated a slightly higher growth of value added (by $151 \%$ ), while in Estonia it was slightly lower $(146 \%)$.

According to the calculations, in Latvia and Estonia one EUR invested in the agricultural sector towards development of fixed assets (total net investment between 2005 and 2013) has resulted in about EUR 0.07 increase in value added (2013 over 2004), while in Lithuania the increase in value added was EUR 0.10.

\section{Distribution of fixed assets and value added}

The pattern of the Lorenz curve allows concluding that, compared to 2004, in the Latvian agricultural sector the concentration of fixed assets and value added has increased, meaning that the development of technological capital in farms of different sizes has proceeded with diverse intensity.

Fig. 3 demonstrates that while in $200410 \%$ of total number of farms (including also farms with standard output (SO) starting from EUR 25-50 thousand) concentrated about one half of the total fixed assets engaged in agricultural production, then in 2013 the top $10 \%$ farms concentrated already $65 \%$ of total fixed assets in the agricultural sector (a 15 percentage point increase), and these farms no longer include farms with SO under EUR 50 thousand. In 2004, about $70 \%$ of total value added in the 
agricultural sector was generated by top $10 \%$ largest (by economic size) farms in Latvia, while in 2013 their share was $80 \%$ of the total value added in the sector (a 10 percentage point increase).

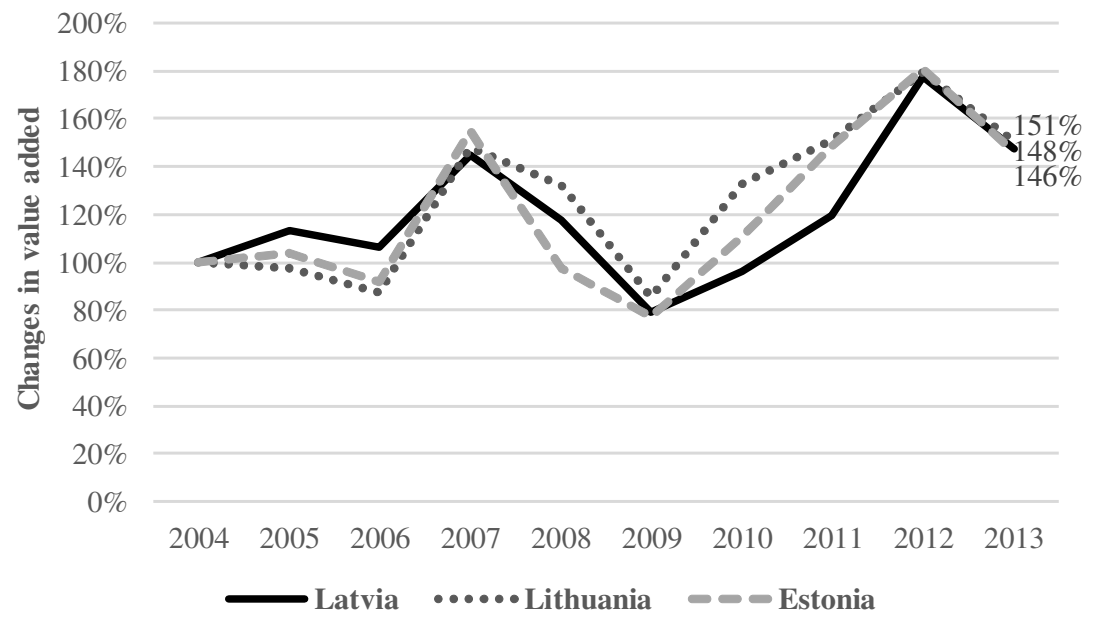

Fig. 2. Development of the value added in the agriculture of Latvia, Lithuania and Estonia in 2004-2013 (2004 = $100 \%)$

a)
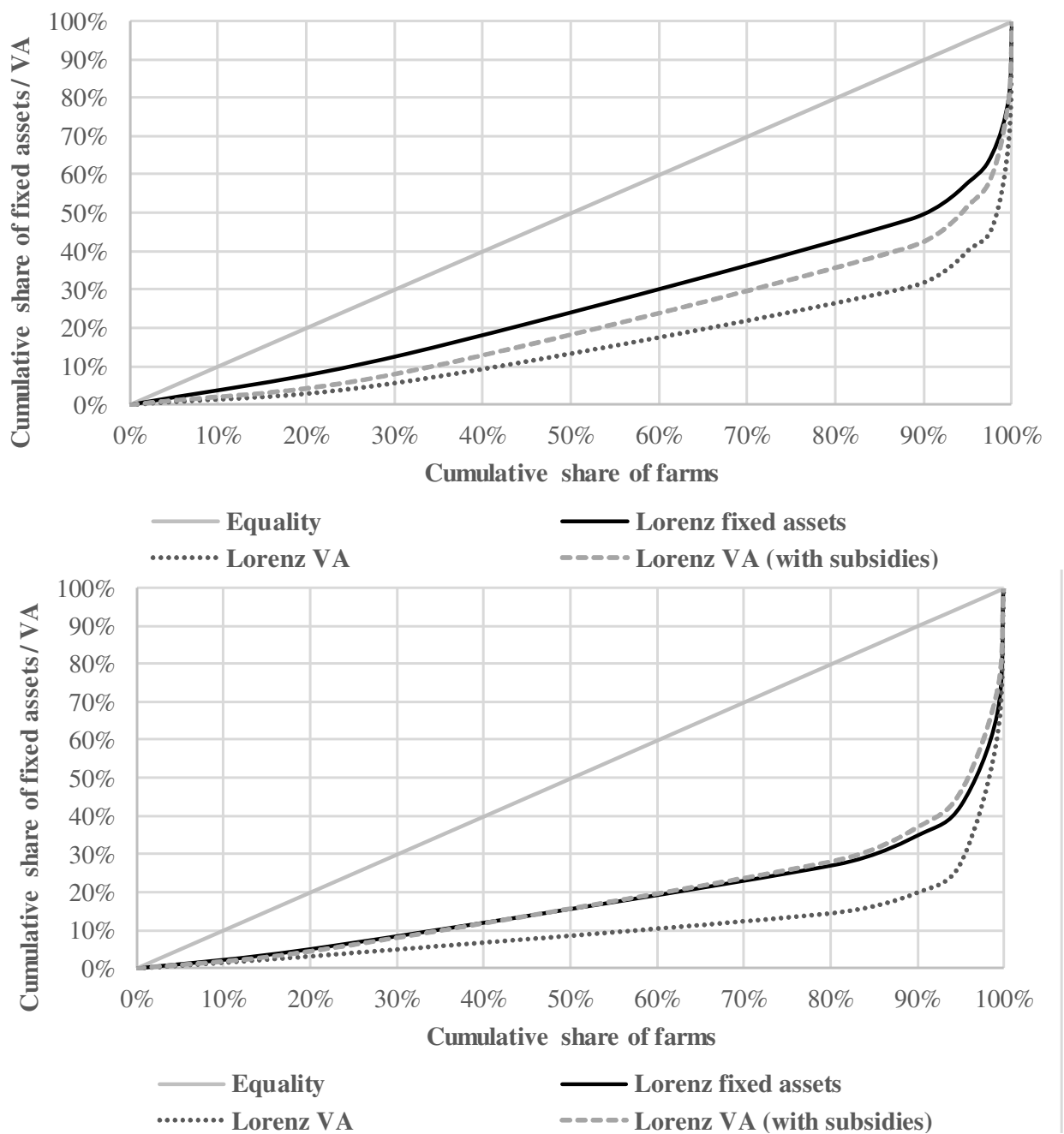

Fig. 3. Distribution of fixed assets and value added in the agriculture of Latvia in 2004 (a) and 2013 (b)

The development of technological capital has triggered structural changes in the Latvian agricultural sector. The share of farms with SO larger than EUR 100 thousand has increased from $2 \%$ in 2004 to $5 \%$ in 2013, and the concentration of fixed assets has become higher in these farms. If in 
2004 the farms pertaining to this group concentrated 1/3 of total value of fixed assets, then in 2013 farms with SO over EUR 100 thousand were holding more than $55 \%$ of total value of fixed assets. In this group of farms, the value added growth rate has been the highest since 2004: the $53 \%$ share in total value added in 2004 has increased to $72 \%$ in 2013 (a 19 percentage point increase).

Though the share of the largest farms (SO over EUR 500 thousand) was negligible both in 2004 and 2013, $0.4 \%$ and $0.7 \%$ of total number of farms respectively, already in 2004 these farms had $20 \%$ of total fixed assets in the sector at their disposal, while in 2013 the concentration of the value of fixed assets in this farm group was as high as $1 / 3$. As to the growth of value added, the share of the largest farm group has increased from $31 \%$ in 2004 to $39 \%$ in 2013 in Latvia.

As a result of the analysis of the development of technological capital in farm groups by their economic size, the calculations suggest that a one euro investment in a farm's fixed assets (net investments in 2005-2013) leads to a differentiated growth in value added (2013/2014). Investing one euro in the development of fixed assets, in the farm group with SO EUR 50-100 thousand the increase of value added was by EUR 0.09 on average, in the farm group with SO EUR 100-500 thousand it was by EUR 0.14 on average, while in the group of largest farms (SO larger than EUR 500 thousand) value added has increased by EUR 0.09 on average.

The trend in the development of technological capital allows concluding that the concentration of value added increases together with the concentration of fixed assets in the farm group concerned. Thus, via a purposeful facilitation of increasing the share of the small and medium-sized farm group (dominating group in terms of farm numbers) in the value of fixed assets, it could be possible to attain an increase of the share contributed to value added by these farms. Conversely, by further encouraging the increase of the share of the farm group with SO over EUR 500 thousand in total fixed assets could lead to ever growing concentration in the agricultural sector.

By analysing the distribution of value added which includes also the balance of current subsidies and taxes in the Latvian agricultural sector, one can conclude that public support promotes a more even distribution of value added across farms of different sizes, which is one of its political aims. Nevertheless, the concentration of value added remains high also with subsidies.

As to the Lithuanian agriculture, in 2013, the distribution of both fixed assets and the generated value added is more even than in Latvia; still, the concentration trend in the development of technological capital is observed in Lithuania as well, if we compare the formation of value added and fixed assets in 2013 and 2006 (there are no data available by farm economic sizes in Lithuania for the years 2004 and 2005).

The pattern of the Lorenz curve (Fig. 4) shows that in 2013 top $10 \%$ largest farms concentrate nearly $50 \%$ of fixed assets and contribute $65 \%$ of total value added by the sector.

Among these top $10 \%$ largest farms in Lithuania, farm with SO over EUR 100 thousand in 2013 concentrate $32 \%$ of total fixed assets and generate nearly half of total value added by the agricultural sector. As to the farm structure in Lithuania, in 2013 the group of farms with SO over EUR 100 thousand were only $3 \%$ of total number of farms. Similar to Latvia, also in Lithuania the share of the large farms (with SO over EUR 500 thousand) in the farm structure is small and was $0.5 \%$ in 2013; however, contrary to Latvia, they concentrate a mere $13 \%$ of total value of fixed assets used in agricultural production, while generating $23 \%$ of total value added by the sector. A lesser dominance of the large farms (with SO over EUR 500 thousand) determines a more even distribution of technological capital in the Lithuanian agricultural sector compared to Latvia.

As to the Estonian agricultural sector, similar to Latvia, in 2013, both the distribution of value of fixed assets at the disposal of agricultural producers and value added was expressly uneven. The pattern of the Lorenz curve (Fig.4) demonstrates that top $10 \%$ largest farms concentrated about $60 \%$ of total fixed assets and contributed $80 \%$ of total value added by the sector. Though there is no information available by farm economic sizes for the period between 2004 and 2007, when we compare 2013 against 2008, also the farms in Estonia demonstrate a concentration trend in the development of technological capital. If compared with other Baltic countries, in Estonia farms with SO over EUR 100 thousand build a relatively high share in the farm structure (11\%), including farms with SO over EUR 500 thousand which were $3 \%$ of total number of farms in 2013, concentrating about $40 \%$ of fixed assets and contributing $56 \%$ of total value added by the sector. With the support 
of subsidies, in Estonia the distribution of value added has been slightly evened out, yet the concentration of value added nevertheless remains high, with top $10 \%$ largest farms dominating.

a)

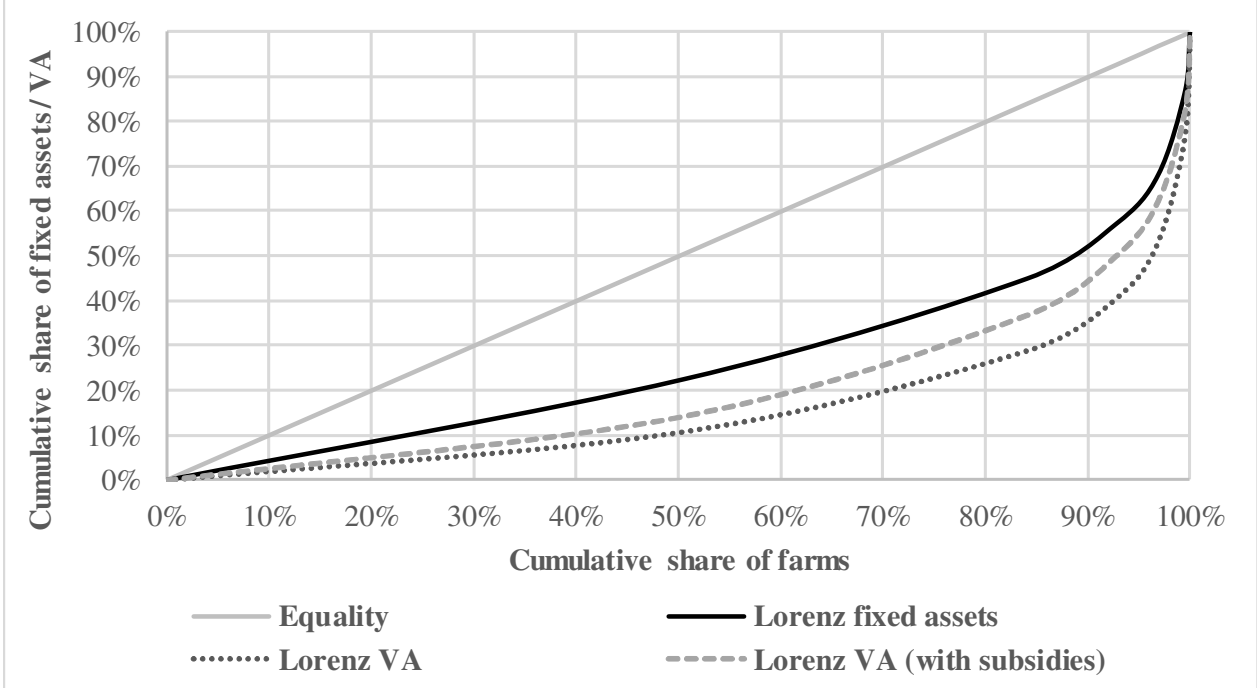

b)

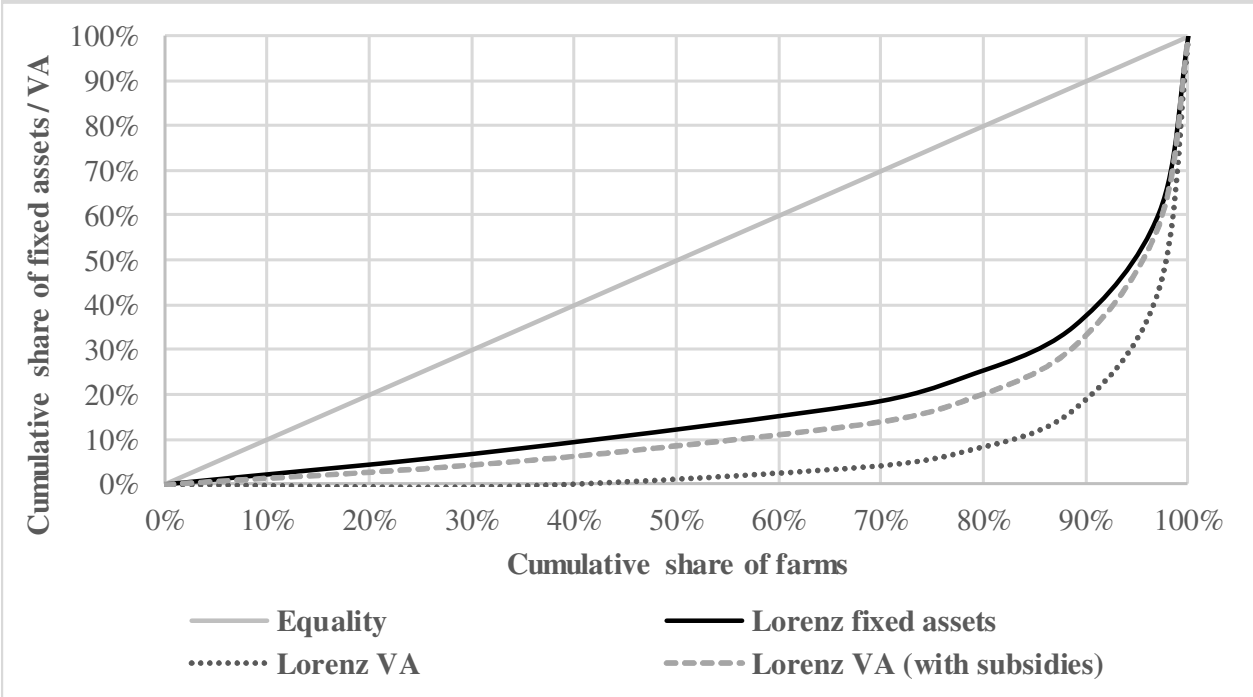

Fig. 4. Distribution of fixed assets and value added in the agriculture of Lithuania (a) and Estonia (b) in 2013

\section{Conclusions}

1. Significant amount of investment in fixed assets has been made in the agriculture of the Baltic countries, along with the increase in the agricultural value added created since 2004.

2. The development of the technological capital in the Baltic countries demonstrates a concentration trend, with a significant increase of the role of the larger farms and their share both in the management of fixed assets required for production and in the generation of value added. However, the distribution of value added in the agriculture of the Baltic countries is expressly uneven in 2013, suggesting an unbalanced development among farms of different economic sizes in the sector.

3. Owing to subsidies, the distribution of value added is evened out; however, this is not sufficient for eliminating the effect of the overall high concentration trend on the agriculture of the Baltic countries.

4. The analysis of technological capital development trends reveals that the concentration of value added increases together with the concentration of fixed assets in the farm group concerned. This implies that a purposeful facilitation of increasing the share of the small and medium-sized farm group (dominating group in terms of farm numbers) in the value of fixed assets would possibly allow attaining an increase of the share in value added contributed by these farms. Conversely, 
any further encouraging of the increase of the share of the farm group with SO over EUR 500 thousand in total value of fixed assets could lead to ever increasing concentration in the agricultural sector.

5. The Latvian example demonstrates that the highest growth of value added (2013/2004) relative to net investments in fixed assets since 2004 has been observed in the farm group with SO EUR 100500 thousand.

\section{Acknowledgements}

The paper was supported by the National Research Programme 5.2.1. SUSTINNO.

\section{References}

1. Leimane I., Krieviņa A., Miglavs A. Improving of Small Farm Market Capability in Latvia. Procedia - Social and Behavioral Sciences, vol. 110, 2014, pp.182-189.

2. Melnikiene R., Volkov A. Impact of the CAP support measures on the Agricultural Sector in Lithuania. Economic, Social and Institutional Factors in the Growth of Agri-food Sector in Europe, vol. 67.1, 2013, pp.112-127.

3. Ex-ante evaluation of the Estonian Rural Development Plan 2014-2020. Final report. [online] [21.02.2017]. Available at: https://www.agri.ee/sites/default/files/content/arengukavad/mak2014/erdp-2014-ex-ante-evaluation-2014-06-16.pdf

4. Petrick M., Tyran E. (2003). Development perspectives of subsistence farms in South-eastern Poland: Social buffer stock or commercial agriculture? [online] [21.02.2017]. Available at: http://www.iamo.de/fileadmin/institute/pub/sr_vol22.pdf

5. Carter C.A., Chen J., Chu B. Agricultural productivity growth in China: farm level versus aggregate measurement. China Econimic Review, vol. 14(1), 2003, pp. 53-71.

6. Chen P.C., Yub M.M., Chang C.C., Hsud S.H. Total factor productivity growth in China's agricultural sector. China Economic Review, vol. 19(4), 2008, pp. 580-593.

7. Alston J. M. The Benefits from Agricultural Research and Development, Innovation, and Productivity Growth. OECD Food, Agriculture and Fisheries Papers, vol. 31, 2010. 26p.

8. Kokins E., Lavrinovičs V. Latvia: Catching-up Towards the World Production Frontier, an Industry Level Analysis. [online] [21.02.2017]. Available at: https://www.makroekonomika.lv/sites/default/files/2016/06/3_kokins_lavrinovics.pdf

9. Koloszko-Chomentowska Z., Sieczko L. Effectiveness of Fixed Assets in Agriculture of Selected New Member States in European Union. [online] [22.02.2017.] Available at: http://tf.llu.lv/conference/proceedings2016/Papers/N130.pdf

10. Grigoriev S. N., Yeleneva J. Y., Golovenchenko A. A., Andreev V. N. Technological Capital: A Criterion of Innovative Development and an Object of Transfer in the Modern Economy, vol. 20, 2014, pp.56-61.

11. Holmes T., McGrattan, Prescott E. Technology Capital Transper. Journal of Economic Theory, vol. 144(6), 2011, pp. 2454-2476.

12. Matthews A. Family farming and the Role of Policy in the EU. [online] [03.03.2017]. Available at: http://capreform.eu/family-farming-and-the-role-of-policy-in-the-eu/

13. European Commission. Structure and dynamics of EU farms: changes, trends and policy relevance. EU Agricultural Economic Brief No 9, 2013. [online] [21.02.2017]. Available at: http://ec.europa.eu/agriculture/sites/agriculture/files/rural-area-economics/briefs/pdf/09_en.pdf

14. Upite I. Investment Support for Agricultural Development in Latvia. Ekonomika ir vadyba: aktualijos ir perspektyvos, vol 3 (16), 2009, pp. 316-323.

15. Koloszko-Chomentowska Z. Selected Effects of Financing of Agricultural Holdings in New Member States of the European Union. [online] [22.02.2017]. Available at: http://e-finanse.com/artykuly_eng/286.pdf.

16. DG Agri. FADN public database. [online] [18.01.2017]. Available at: http://ec.europa.eu/agriculture/rica/database/database_en.cfm

17. Pavkova K., Currie G., Delbosc A., Sarvi M. Selecting tram links for priority treatments - The Lorenz Curve approach. Journal of Transport Geography, vol. 55, 2016, pp. 101-109. 